\section{Combination of Cross- Species RNA Solution Hybridization and Immunoprecipitation Aids in the Cloning of
RT-PCR Products}

BioTechniques 26:616-618 (April 1999)

cDNA cloning by means of reverse transcription-polymerase chain reaction (RT-PCR) is a widely used technique. Ever since the first published method by Veres et al. (6), it has supplanted conventional methods of cDNA cloning due to its ease and speed. However, there are certain constraints that are associated with this technique; e.g., it requires the knowledge of a few nucleic acid sequences of the gene of interest. These can be obtained by either microsequencing the protein itself followed by the construction of a putative cDNA sequence or, more commonly, by using the homologous cDNA sequence from other species. However, both methods use degenerate primers $(4,5)$, which can give rise to nonspecific priming (2). Therefore, variations of PCR have been developed to overcome this problem, e.g., touchdown PCR (3) and nested PCR (1). However, none of the techniques has been used successfully in our laboratory to clone the rabbit serotonin (5-hydroxytryptamine, 5HT) type 3 receptor from the retina using degenerate primers based on a rat sequence (unpublished sequence data; GenBank $^{\circledR}$ Accession No. U59672). Although additional manipulations of PCR methods and reagents were attempted, none of these was successful in obtaining the rabbit $5-\mathrm{HT}_{3}$ receptor gene coding regions. Indeed, very often, gel analysis of PCR products showed multiple bands (Figure 1A), none of which, after subsequent cloning and sequencing, was homologous to the $5-\mathrm{HT}_{3}$ gene. Thus, our difficulties could, in part, arise because the level of $5-\mathrm{HT}_{3}$ receptor RNA in the rabbit retina is extremely low. Furthermore, the degenerate primers could also have annealed with other more abundant genes that can serve as fortuitous templates. Consequently, even though the $5-\mathrm{HT}_{3}$ transcripts could be amplified by this method, they might be obscured by amplification of the other more abundant genes that are amplified at the same time.

This prompted us to devise an alternative that would improve the specificity of cDNA cloning using degenerate primers. Our method is based on the premise that cross-species pairing for long stretches of the same genes is sufficiently high; e.g., between either RNA and DNA or DNA and DNA strands. Once the duplex is formed, it can be selectively retrieved by immunoprecipitation. Thus, if a gene sequence is known in one species, appropriate RNA or DNA probes can be generated and used to identify and isolate the same gene in different species. Although this method is given in detail for our gene of interest, it can be easily adapted for a broad range of applications by those molecular biologists interested in the evolution of specific genes, comparative studies of gene structure and some clinical applications, e.g., the simultaneous identification of multiple strains of infectious agents such as human immunodeficiency virus (HIV).

First, rat 5- $\mathrm{HT}_{3}$-digoxiginin (Dig)labeled RNA probes were generated using in vitro transcription with a DIG RNA Labeling Kit (SP6/T7) (Boehringer Mannheim, Indianapolis, IN, USA). A cloning vector with a rat 5$\mathrm{HT}_{3}$ insert that we had previously cloned (unpublished data) was used. Next, standard RT-PCR on rabbit retina RNA was performed using degenerate primers with the exception that the annealing temperature was slightly decreased to make sure that the gene of interest, in our case, the rabbit $5-\mathrm{HT}_{3}$ receptor, was present in the PCR product. The RNA isolation was performed using RNAzol ${ }^{\mathrm{TM}} \mathrm{B}$ (Tel-Test, Friendswood, TX, USA) according to the manufacturer's instructions. First-strand cDNA synthesis was performed using SUPERSCRIPT $^{\mathrm{TM}}$ II RNase $\mathrm{H}^{-}$Reverse Transcriptase (Life Technologies, Gaithersburg, MD, USA) according to the manufacturer's instructions. The PCR was: $2.5 \mu \mathrm{L}$ of $20 \times$ Enzyme Buffer (1.0 M Tris-HCl, pH 9.0, 0.4 M ammonium sulfate), $1 \mu \mathrm{L}$ dNTP mixture $(2.5 \mathrm{mM}$ each of dATP, dCTP, dGTP, dTTP), $0.5 \mu \mathrm{g}$ of each of the primers and $1 \mathrm{mM} \mathrm{MgCl}$. The reaction was run in a PTC-100 ${ }^{\mathrm{TM}}$ Thermal Cycler (MJ Research, Watertown, MA, USA) as follows: $94^{\circ} \mathrm{C}$ for $4 \mathrm{~min}$ (hot start), 35 cycles of $94^{\circ} \mathrm{C}$ for $45 \mathrm{~s}$ (denaturation), $50^{\circ} \mathrm{C}$ for $45 \mathrm{~s}$ (annealing) and

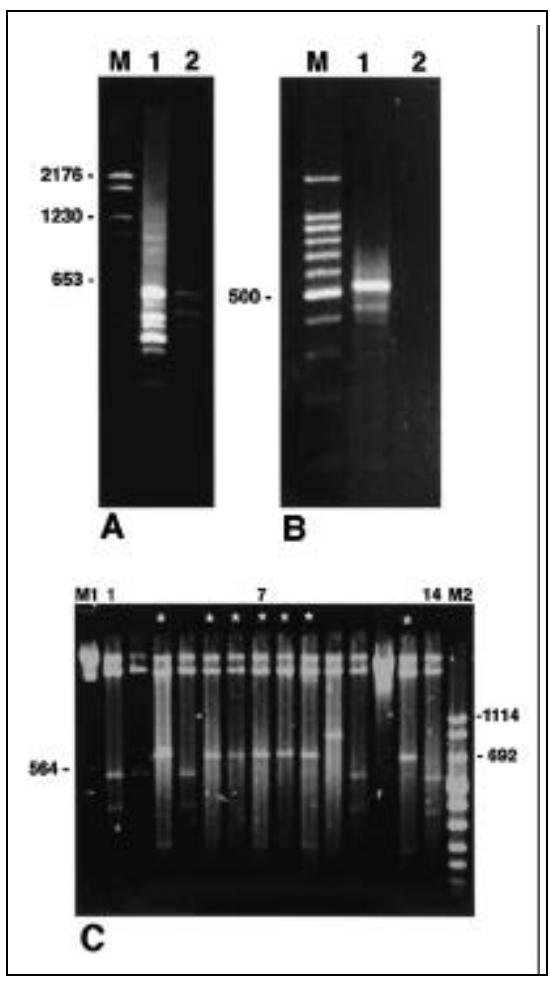

Figure 1. Solution hybridization and immunoprecipitation followed by another round of PCR results in high-fidelity amplification of target genes. (A) Standard PCR was performed on rabbit retina cDNA (lane 1) and rat brain cDNA (lane 2). Multiple bands of PCR products were obtained in the rabbit retina; whereas, in rat brain, greater specificity is suggested by a more limited number of bands. $\mathrm{M}=$ DNA standard (Molecular Weight Marker VI; Boehringer Mannheim). The primers were: F1(D) $5^{\prime}$-gaa$\mathrm{gt}(\mathrm{c} / \mathrm{t}) \mathrm{ca}(\mathrm{a} / \mathrm{g}) \mathrm{aa}(\mathrm{c} / \mathrm{t}) \mathrm{ta}(\mathrm{c} / \mathrm{t}) \mathrm{aa}(\mathrm{a} / \mathrm{g})-3^{\prime}$ and B 1 (D) $5^{\prime}$ catgca $(\mathrm{a} / \mathrm{c} / \mathrm{g} / \mathrm{t}) \mathrm{ac}(\mathrm{a} / \mathrm{c} / \mathrm{g} / \mathrm{t}) \mathrm{ac}(\mathrm{a} / \mathrm{g}) \mathrm{aa}(\mathrm{a} / \mathrm{g}) \mathrm{ta}-3^{\prime}$. (B) The second round of PCR following solution hybridization and immunoprecipitation resulted in fewer extraneous bands (lane 1) from retina. One prominent band of the right size is present (ca. $510 \mathrm{bp}$ ), as well as a few minor ones. Lane 2 is a water control. $\mathrm{M}=100$-bp ladder (Promega, Madison, WI, USA). (C) $50 \%$ of the subclones demonstrate inserts of the expected size by restriction digests. After the second round of PCR, the expected band (510 bp) was excised and purified. The DNA was ligated into a TA Cloning Vector (Novagen, Madison, WI, USA) and used to transform competent cells. Minipreps were performed, and the DNA was digested with $P v u \mathrm{II}$ and runs on a $1 \%$ agarose gel. Lanes 3,5-9 and 13 (stars) show the expected insert size. M1 = $\lambda /$ HindIII markers. M2 = DNA standard (Molecular Weight Marker VIII; Boehringer Mannheim). 


\section{Benchmarks}

$72^{\circ} \mathrm{C}$ for 2 min (extension), with an additional final extension time of $10 \mathrm{~min}$. Multiple PCRs were performed to ensure that the putative PCR product was present in sufficient quantity. The PCR products were pooled and extracted with phenol/chloroform (1:1, vol/vol). The DNA was precipitated in $2.5 \mathrm{vol}$ of absolute ethanol and $0.1 \mathrm{vol}$ of $3 \mathrm{M}$ sodium acetate, $\mathrm{pH} 5.3$, for $1 \mathrm{~h}$ on dry ice. The resulting DNA pellet was resuspended in an appropriate volume of diethyl pyrocarbonate (DEPC; Sigma, St. Louis, MO, USA)-treated water.

Next, solution-hybridization was performed at $45^{\circ} \mathrm{C}$ for $16 \mathrm{~h}$ on the rabbit PCR products and the Dig-labeled rat 5 $\mathrm{HT}_{3}$ RNA probes. The final hybridization buffer consisted of $60 \%$ formamide, $77.5 \mathrm{mM}$ sodium citrate, $\mathrm{pH}$ 6.4, 232.5 $\mathrm{mM}$ sodium acetate, $\mathrm{pH} 6.4$, and 0.78 $\mathrm{mM}$ EDTA, $\mathrm{pH} 8.0$, in a final volume of $200 \mu \mathrm{L}$. The next day, $1 \mathrm{~mL}$ of DEPCtreated water was added to bring the salt concentration to a physiological level for subsequent immunoprecipitation. At this step, the RNA-DNA hybrids should have formed. Immunoprecipitation of these RNA-DNA hybrids was performed by incubating them in $100 \mu \mathrm{L}$ of Anti-digoxin Agarose (Sigma) for $2 \mathrm{~h}$ with gentle shaking at room temperature. After $2 \mathrm{~h}$, the agarose bead-antibody-DNA-RNA complex was centrifuged at $16000 \times g$ for $2 \mathrm{~min}$. The supernatant was discarded, the bead-antibody-DNA-RNA complex was washed $3 \times$ with TBS-T $(0.05 \mathrm{M}$ Tris, $\mathrm{pH} 8.0$, $0.15 \mathrm{M} \mathrm{NaCl}, 0.05 \%$ Tween ${ }^{\circledR}-20$ ) and then resuspended in the appropriate volume of double-distilled water. The DNA-RNA hybrids were separated by denaturing at $95^{\circ} \mathrm{C}$ for $3 \mathrm{~min}$ and immediately cooled on ice. Subsequently, 5 $\mu \mathrm{L}$ of RNase A $(10 \mathrm{mg} / \mathrm{mL})$ (Boehringer Mannheim) were added, and the mixture was incubated at $37^{\circ} \mathrm{C}$ for 30 min to ensure that the RNA probes were completely degraded, thus preventing cross contamination in the subsequent PCR step. Another round of phenol/ chloroform extraction was performed to isolate the DNA from the Dig, digoxin and antibodies, all of which are soluble in phenol. The DNA remaining in the aqueous phase was precipitated and amplified by another round of PCR using the same degenerate primers. At this step, one major product of the expected size and few minor products were obtained (Figure 1B), which is better than results obtained by a conventional PCR (Figure 1A). Subsequently, standard PCR cloning was performed.

Analysis of the subclones by restriction digestion with PvuII (New England Biolabs, Beverly, MA, USA) showed that 7 out of 14 clones contained the correct size insert (Figure 1C). One of these was picked out and sequenced, which revealed that it is indeed the rabbit $5-\mathrm{HT}_{3}$ receptor (GenBank Accession No. AF121107).

In conclusion, we have developed a novel method of using solution hybridization and immunoprecipitation coupled to PCR to isolate specific PCR products. In so doing, we have successfully amplified and cloned a rabbit 5$\mathrm{HT}_{3}$ receptor from the retina. This technique, as described above, has broad applicability to evolutionary and comparative molecular biology since it can be used in cross-species studies of single genes. Moreover, variations of this technique could involve multiple nucleic acid conjugates, e.g., biotin, fluorescein or Dig for labeling RNA or DNA probes. Thereby, multiple genes or variants of the same gene could be extracted from a single sample simultaneously. Ensuing PCR analysis then would not be dominated by the major gene variants. This latter modification would be a powerful tool in both clinical molecular diagnostic work, where isolation of multiple strains of infectious organisms is important to the clinical management and in molecular phylogenetic studies of gene duplications in organisms such as zebrafish and xenopus.

\section{REFERENCES}

1.Albert, J. and E.M. Fenyo. 1990. Simple, sensitive, and specific detection of human immunodeficiency virus type 1 in clinical specimens by polymerase chain reaction with nested primers. J. Clin. Microbiol. 28:1560-1564.

2.Carmody, M.W. and C.P.H. Vary. 1994. An empirical method for the estimation of nonspecific PCR primer derived genomic reactivity. BioTechniques 16:1044-1050.

3.Don, R.H., P.T. Cox, B.J. Wainwright, K. Baker and J.S. Mattick. 1991. "Touchdown" PCR to circumvent spurious priming during gene amplification. Nucleic Acids Res. 19:4008.

4.Girgis, S.I., M. Alevizaki, P. Denny, G.J.M. Ferrier and S. Legon. 1988. Generation of DNA probes for peptides with highly degenerate codons using mixed primer PCR. Nucleic Acids Res. 16:10371.

5.Lee, C.C., X. Wu, R.A. Gibbs, R.G. Cook, D.M. Muzny and C.T. Caskey. 1988. Generation of cDNA probes directed by amino acid sequence: cloning of urate oxidase. Science 239:1288-1291.

6.Veres, G., R.A. Gibbs, S.E. Scherer and C.T. Caskey. 1987. The molecular basis of the sparse fur mouse mutation. Science 237:415417.

Address correspondence to Mr. Kusol Pootanakit, Cutaneous Biology Research Center, 3rd Floor, Bldg. 149 MGH-East, Charlestown Navy Yard - 13th Street, Charlestown, MA 02129, USA. Internet: kusol.pootanakit@cbrc2.mgh.harvard.edu

Received 07 October 1998; accepted 21 January 1999.

Kusol Pootanakit and William

\section{J. Brunken}

Boston College

Chestnut Hill and

Massachusetts General Hospital

Charlestown, MA, USA 